näjällä samassa suhteessa kuin lännessä. Se ei olisi eettistä. Kyse on etiikasta eikä etiketistä, joka on etiikan trivialisointia. Täytyy olla hienovarainen. Tekijän kuoleman juhliminen olisi absurdia tässä yhteydessä.

Keskustelemassa David Shepherdin lisäksi:

Viola Parente-Čapková

Elsi Hyttinen

Kaisa Kurikka

Milla Peltonen

Veli-Matti Pynttäri

Lea Rojola

\section{Onko pervouttamisella mitään rajaa?}

Pervot puheet: teorian ja aktivismin risteymiä. Turun 5. valtakunnallinen lesbo-, homo- ja queer-tutkimusseminaari. Åbo Akademi 21.-23.10.2005

Kirjallisuuden- ja taiteentutkijoita aina kiinnostava Turun valtakunnallinen lesbo-, homo- ja queer-tutkimusseminaari järjestettiin tänä vuonna Åbo Akademissa. Teemana oli teorian ja aktivismin kohtaaminen. Seminaari, joka koostui niin ulkomaisista kuin kotimaisista luennoitsijavieraista, työryhmistä ja paneelikeskustelusta, osui ajan hermoon. Onhan koko syksyn Suomessa jännitetty ja kauhisteltu Ruotsissa alkanutta poliittista, median inspiroimaa, konservatiivista takaiskua. Feministisen puolueen (FI) ympärille kietoutuneen näytelmän näkyvimmäksi kohteeksi on joutunut Pohjolan tunnetuin queer-teoreetikko ja aktivisti, suomalaissyntyinen teatterintutkija ja Tukholman yliopiston professori Tiina Rosenberg. Ruotsin tilanne puhutti luonnollisesti seminaariväkeä; suomalaisen ja ruotsalaisen julkisuuden ja julkisen keskustelun eroja pohdiskeltiin useaan otteeseen.

Kirjallisuudentutkijalle Pervot puheet avasi erityisesti uusia näkökulmia tekstuaalisuuden ja queeriyden suhteen. Pervous ei ilmene pelkästään kirjallisesti, vaan tekstuaaliseksi queeriksi näyttää 
muuttuvan koko kulttuuri. Rosenberg huomautti useaan otteeseen, että kulttuuri on itsessään pervo, mutta ihmisillä on vimma normaalistaa se. Esimerkiksi lesbouden moniaalle ulottuvia koodeja ja tyylejä kirjaimellisesti kannetaan, kuten ruotsalaisen tutkijan Ulrika Dahlin ja tunnetun kirjallisuudentutkijan Reina Lewisin pukeutumista ja tyyliä koskevista luennoista saimme oppia. Queeria myös kuullaan, ja niinpä Suomen musikologit järjestäytyivät ensimmäistä kertaa queer-musikologian pariin. Meri Kytö havainnollisti sekä partituurista käsin että musiikkinäyttein queereja murtumia kreikkalais-ranskalaisen säveltäjän Iannis Xenaksiksen teoksesta Kassandra, jonka nimiosa on sävelletty baritonille. Susanna Välimäki esitelmöi taas Mike Nicholsin ohjaaman Angels in American tv-sarjaversion musiikkimaailmasta. Thomas Newmanin säveltämästä queerista musiikista - kosmisesta kohinasta - voidaan löytää jopa hybridejä soittimia.

Queerittaminen ei rajoitu puvustukseen tai äänimaailmaan, vaan myös väri tai sen runsaus voi olla oire pervosta. Tämä kävi ilmi taidehistorioitsija Harri Kalhan esitelmästä, joka koski Magnus Enckellin värinkäytön outoutta ja runsautta tämän Italian matkan jälkeisessä tuotannossa. Tämä Suomen kultakauden ”suoran viivan mestari” vajosi outoon, värikylläiseen passiivisuuteen, jonka tunnusmerkeiksi tulivat uinuviin asentoihin taipuneet kauniit faunit. Väriin sortuneen Enckellin kohtalo Suomen taidehistorian kiusallisena avoimena salaisuutena oli valmis.
Yksi seminaarin helmistä oli eittämättä Anu Koivusen, Leena-Maija Rossin ja Tiina Rosenbergin romanssia käsitellyt työryhmä, joka purki lesbouden ja muunkinlaisen ei-normatiivisen seksuaalisuuden kuvaamista suosituissa tv-sarjoissa. Mitä tapahtuu sitkeästi voimansa pitävälle romanssin lajille, kun se queerittuu? Kun homojen ja lesbojen kuvaaminen valtavirtaistuu, tapahtuukin uusia queereja säröjä. Kenestä tulee normilesbo, ja kuka marginalisoituu epäonnistumisen logiikalle perustuvaan surumieliseen ylevyyteen eli camp-diivan rooliin? Tällaisia kysymyksiä esitettiin romanssi-työryhmässä, jonka aiheet liikkuivat niin sukupuolten valtapositioita kyseenalaistavassa Mullan alla -sarjassa kuin brittiläisissä tv-sarjoissa, jotka kuuluvat historiallisten pukuelokuvien alalajiin, queer-pukuelokuviin.

Pervoissa puheissa puhuttiin paljon onhan pervoilla pervot puheensa. Teoriaa ja aktivismia mietittiin niin akateemisen tutkimuksen kannalta kuin esimerkiksi lainsäädäntötyön vinkkelistä. Varsovan yliopiston tutkija Joanna Mizielinska valotti queer-teorian soveltamista eri ympäristöissä kuten Suomessa ja Puolassa ja huomautti amerikkalaisperäisen teorian muuntautumiskyvystä sekä queer-teorian haastamisen tärkeydestä toisissa kulttuurisissa ympäristöissä. Edistyksellisen lainsäädäntötyön ajamisessa on myös sokeat pisteensä. Parisuhdelakiin ja hedelmöityshoitoihin keskittynyt aktivismi on kadottanut pervoaikansa, kuten Pia Livia Hekanaho toi esille kriittisessä ja 
älykkäässä luennossaan. Häpeäorientoitunut homo- ja lesbokulttuuri on aiemmin ammentanut luovuutensa kielletystä ja torjutusta pervokulttuurista kieltäytyen samalla astumasta normaaliaikaan (aviopuoliso, perhe, lapset, aikuisuus, perintö jne.). Nyt malliaikaan siirtyessään se näyttää riemulla unohtavan oman menneisyytensä ja tulevan heterommaksi kuin heterokulttuuri ikänään.

Vielä on yksi asia queerittamatta ja se on maisema. Pervot puheet -seminaarin päätti nimittäin sunnuntainen retki Nautelankoskelle. Tutustumisretken kohteena oli edesmenneen maanviljelijän, keräilijän ja maamme arvostetuimman harrastelija-arkeologin Lauri Nautelan museo, joka sijaitsee Liedossa. Itsessään ihastuttava museorakennus sijaitsee kulttuurihistoriallisesti merkittävällä suojelualueella. Koskialuemiljöössä asustelevat muun muassa äärimmäisen harvinainen lettosiemenkotilo, niukkoina kasvavat, nuokkuvakukkaiset hoikkaängelmät sekä Sokrateen kuolemasta meille niin tuttu, synkänoloinen myrkkykeiso. Kasvit ja eläimet ovatkin Nautelankoskella usein harvinaislaatuisia kummajaisia. Se ei ole ihme, sillä outous viihtyy Nautelankoskella.

Nautelankosken museon vielä luokittelemattomat ja yleisön ulottumattomissa olevat kokoelmat ovat suomalaisen agraariyhteisöllisen homohistorian tärkeä löytö. Aineisto esiteltiin nyt ensimmäisen kerran ulkopuolisille eli Pervot puheet seminaarin tutkijoille. Tähän Lauri Nautelan merkittävään homohistorialliseen kokoelmaan kuuluu muun muassa noin 7000 niteen kirjasto, valokuvakokoelmia ja maailman anomalioista täyttyvä lehtileikearkisto. Nautelan kirjastossa on paljon historiallista ja seksologista kirjallisuutta sekä maailman kulttuureja käsitteleviä teoksia, puhumattakaan arkeologiasta. Lauri Nautelan kirjasto on kirjallisuudentutkijan aarreaitta, monimutkainen kryptinen rihmasto, jossa teokset viittaavat toisiinsa, kirjat ovat täynnä alleviivauksia ja kommentteja ja niistä saattaa lukea, miten homoeroottisen halun kartasto piirtyi ja siirtyi kirjasta toiseen, sivulta toiseen, sanasta toiseen ja kuvasta toiseen.

Queer-tutkimus jatkuu ja kuin Lauri Nautelaa ajatellen seuraavan seminaarin teemaksi ehdotettiinkin (pohjoista) historiaa. Tämä asettaa haasteita myös erityisesti suomalaisen kirjallisuuden tutkijoille - onhan kirjallisuutemme kaanon aika pervo.

\section{Lasse Kekki}

